\title{
Ambulatoriškai vartojamo
}

\section{azitromicino vaidmuo gydant visuomenèje igytą pneumoniją}

Rūta Nutautienè

LSMU MA Pulmonologijos ir imunologijos klinika

Reikšminiai žodžiai: visuomenèje igyta pneumonija, gydymas, makrolidai, azitromicinas.

Santrauka. Visuomenejje igyta pneumonija (VIP) pasaulyje sergama gana dažnai, o jos sukèlejjas nustatomas rečiau nei 50 proc. atvejų, ambulatoriškai gydomiems pacientams dažniausiai net netiriamas. Remiantis tyrimų duomenimis ir rekomendacijomis, dažniausiai VlP gydyti antibiotikų skiriama empiriškai, taigi jie turi veikti Streptococcus pneumoniae, Haemophilus influenzae, Mycoplasma pneumoniae, Chlamydia pneumoniae ir Legionella pneumophila.

Makrolidai, ypač naujos kartos (azitromicinas), yra mažiau toksiški ir geresnes farmakokinetines savybes turintys alternatyvūs vaistai, vartotini, kai pacientas netoleruoja pirmos eilès vaisto. Klinikinių tyrimų rezultatai rodo, kad triju dienų trukmès gydymas azitromicinu yra efektyvus ir saugus gydant viršutinių bei apatinių kvèpavimo takų infekcines ligas kasdienèje klinikinèje praktikoje.

Visuomenèje igyta pneumonija (VỊP) pasaulyje sergama gana dažnai, vien JAV diagnozuojama $4 \mathrm{mln}$. pneumonijos atveju per metus [1]. Stiprios ekonomikos šalyse mirtys nuo pneumonijos užima $5-6$ vietą mirties priežasčių struktūroje [2].

Pneumonijos sukèlèjas nustatomas rečiau nei 50 proc. atvejų, o ambulatoriškai gydomiems pacientams dažniausiai ir netiriamas $[3,4]$. Remiantis tyrimų duomenimis ir rekomendacijomis, dažniausiai VỊP gydyti antibiotikų skiriama empiriškai, taigi jie turi veikti Streptococcus pneumoniae, dažniausią sukèlëją, taip pat Haemophilus influenzae, pageidaujama, kad veiktu ir atipinius sukèlèjus (Mycoplasma pneumoniae, Chlamydia pneumoniae ir Legionella pneumophila).

Lietuvoje priimtame pneumonijos gydymo sutarime rekomenduojama, kad empirinis antibiotiku pasirinkimas priklausytų nuo numanomo ligos sukèlëjo, paciento amžiaus, gretutinių ligų ir rizikos veiksnių bei pneumonijos sunkumo.

Lietuva priskiriama mažo S. pneumoniae atsparumo beta laktaminiams antibiotikams sričiai, todèl VỊP gydyti ambulatorinėmis sąlygomis šios grupès vaistai turi būti pasirenkami pirmiausia. Makrolidụ poveikis $H$. influenzae nèra pakankamas, nors jis ir veikia M. pneumoniae. Pažymètina, kad S. pneumoniae atsparumas makrolidams vystosi daug dažniau negu beta laktaminiams antibiotikams. Mūsų šalies laboratorijų duomenimis, Lietuvoje išskiriamos S. pneumoniae padermès taip pat atsparesnès eritromicinui, o ne penicilinui.

Makrolidai, ypač naujos kartos (azitromicinas), yra mažiau toksiški, geresnių farmakokinetinių savybių nei eritromicinas, - jie alternatyvūs vaistai, vartotini kai netoleruojamas pirmaeilis vaistas [5].

\section{KLINIKINĖ PROBLEMA - BAKTERIJŲ ATSPARUMAS ANTIBIOTIKAMS}

Antibiotiku vartojimas ir su juo susijęs bakterijų atsparumas antibiotikams - labai aktualios ir dažnai medicinos spaudoje aptariamos temos. Pasaulyje didèja patogeninių bakterijụ atsparumas dažniausiai vartojamiems antibakteriniams preparatams [6]. Daugelio tyrimų duomenys rodo, kad kuo daugiau 
antibiotiku vartojama, tuo didesnis bakterijų atsparumas jiems. Per pastaruosius 40 metu literatūroje labai padaugejo pranešimų apie penicilinui atsparias Streptococcus pneumoniae padermes. Kai kuriose šalyse nustatytas tokių pneumokokų dažnumas kelia didžiuli nerimą: pranešama, kad daugiau nei 80 proc. pneumokokų, išskirtų kai kuriose Vidurio ir Rytų Europos valstybèse [7], ir 25 proc. pneumokokų, išskirtų kai kuriuose Ispanijos gydymo centruose, yra atsparūs penicilinui [8].

Kalbant apie beta laktaminių antibiotikų farmakokinetiką, būtina paminèti didejjančią jų minimalią inhibicinę koncentraciją (MIK). Beta laktaminiai antibiotikai (penicilinai, cefalosporinai) sunkiai pereina per ląstelès sienelę [9]. Juc koncentracija neląsteliniame skystyje analogiška koncentracijai serume. Lyginant beta laktaminių antibiotikų mikroorganizmus slopinančią minimalią koncentraciją ir serumo koncentraciją, galima spęsti apie gydymo in vivo veiksmingumą. Jei beta laktaminių antibiotikų koncentracija serume mažesnè už konkretų patogeną slopinančią minimalią koncentraciją, gydymas bus neveiksmingas. Ilgą laiką didejančios mikroorganizmą slopinančios minimalios antibiotiko koncentracijos problema būdavo įveikiama paprasčiausiai didinant vaisto dozę: atradus peniciliną, gydymo kursui pakakdavo dešimčių tūkstančių veikimo vienetų, o dabar skiriami milijonai. Tačiau dozès negalima didinti be galo, todèl ši taktika didejjant MIK tampa nebe tokia efektyvi [10].

Nustatytas ir imunosupresinès būklès pacientu S. pneumoniae atsparumas makrolidams bei azalidams in vitro. Išskiriamos dvi atsparių padermių grupès: kai MIK 4-16 mg/l ir kai MIK > $128 \mathrm{mg} / \mathrm{l}$ (rečiau) [11]. Taip pat išskirti ir Mycobacterium avium kompleksai (MAK) AIDS sergantiems pacientams, kurių klaritromicino MIK > $32 \mathrm{mg} / \mathrm{l}$ [12].

Penicilinams ir pirmos kartos cefalosporinams atsparių mikroorganizmų iš tiesų daugeja. Pasak kelių tyrèjų, dèl palyginti nedidelès kai kurių makrolidų, ir ypač azalidų pogrupio atstovo azitromicino, koncentracijos serume padaugèjo publikacijų apie atsparumą minetiems preparatams in vitro. Šis teiginys grindžiamas principu, jog maža koncentracija serume yra nepakankamai veikminga mikroorganizmo inhibicijai garantuoti, t. y. skatina atsparios populiacijos dauginimąsi $[13,14]$. Kita hipotezè iškelia prielaidą, jog maža koncentracija serume taip pat gali būti gydymo nesèkmès bei padidejusio sergamumo ir mirštamumo dèl nepakankamai efektyvaus bakterijų pašalinimo iš kraujotakos (bakteriemijos) priežastis. Ivertinus farmakokinetines ir farmakodinamines makrolidų savybes, tampa aišku, kad šios baimès nepagrịstos. Be abejo, MIK didejjimas in vitro turi būti vertinamas kaip perspèjimas, ypač kalbant apie kai kuriuos trumpo pusinès eliminacijos laiko makrolidus, tačiau tokių duomenų klinikinè svarba dar turi būti ịvertinta. Šis teiginys ypač svarbus kalbant apie azalidą azitromiciną, kurio farmakologinès ypatybès iškreipia vien laboratoriniais duomenimis pagrịstus gydymo standartus. Azitromicinui būdinga maža koncentracija serume ir didelè koncentracija audiniuose [15], kaupimasis ir ilgalaikis išsilaikymas fagocituojančiose ląstelèse [16], ilgas pusinès eliminacijos laikas [17, 18]. Dèl šių savybių bakterinès kilmès kvẻpavimo takų ligoms gydyti azitromiciną (Sumamed) pakanka vartoti 3-5 dienas kartą per parą.

\section{AZITROMICINAS - NAUJOS MAKROLIDŲ KLASĖS ANTIBIOTIKAS}

Azitromicinas - pirmasis azalidų, naujos makrolidų klasès, antibiotikas, veikiantis bakterijose vykstančią baltymų sintezę. Vaistas pasižymi plačiu veikimo spektru [19-21]:

- gramteigiamos bakterijos: Streptococcus pneumoniae, S. pyogenes, S. galactiae, S. viridans, C, F, G grupiu streptokokai, Staphylococcus aureus;

- gramneigiamos bakterijos: Haemophilus influenzae, $H$. parainfluenzae, $H$. ducreyi, Moraxella catarrhalis, Bordetella pertussis, B. parapertussis, Legionella pneumophila, Brucella melitensis, Helicobacter pylori, Campylobacter jejuni, Neisseria gonorrhoeae, Gardnerella vaginalis;

- anaerobinès bakterijos: Bacteroides bivius, Clostridium perfringens, Peptostreptococcus rūšis, Peptococcus rūšis;

- kiti mikroorganizmai: Clamydia trachomatis, C. pneumoniae, Mycoplasma pneumoniae, Ureaplasma urealyticum, Treponema pallidum, Borrelia burgdorferi.

\section{Trumpas azitromicino (Summamed) vartojimas pagrịstas klinikiniais tyrimais}

Azitromicino vartojimas klinikinèje praktikoje ivertintas tarptautiniu daugiacentriu klinikiniu tyrimu Sumamed poregistracinis tyrimas gydant kvepavimo taku infekcines ligas (RTI) (SuPoRTI)(22), kuris buvo vykdomas 2008-2009 metais 25 centruose (3 šalyse). Tyrime dalyvavo 580 pacientų.

Pagrindinis klinikinio tyrimo tikslas - juertinti azitromicino klinikini veiksmingumą gydant kvejpavimo takų infekcinėmis ligomis sergančius suaugusiuosius ir vaikus. Üminiam faringitui/tonzilitui (ŪF/T), ūminiam sinusitui (ŪS), ūminiam vidurinès ausies uždegimui (ŪVAU), lètinio bronchito paūmèjimui (LBP), visuomenèje igytai pneumonijai (VIP) gydyti skirtas 3 dienų azitromicino kursas.

Tyrimo trukmè $-10(+2)$ arba $28(+4)$ dienos, 3 (viršutinių kvėpavimo takų infekcijos) arba 4 (apatinių kvėpavimo takų infekcijos) apsilankymai pas gydytoją, kurių metu klinikinis azitromicino veiksmingumas buvo vertinamas pagal bendruosius klinikinius rezultatus: objektyvius klinikinius duomenis bei atliekama ligoniu apklausa pagal subjektyvius pasveikimo rodiklius. Kiekvieno apsilankymo metu ligoniai buvo kliniškai ištiriami: apklausiami, apžiūrimi, jiems atliekami kraujo ir bakteriologiniai tyrimai (skreplių, nosiaryklès 


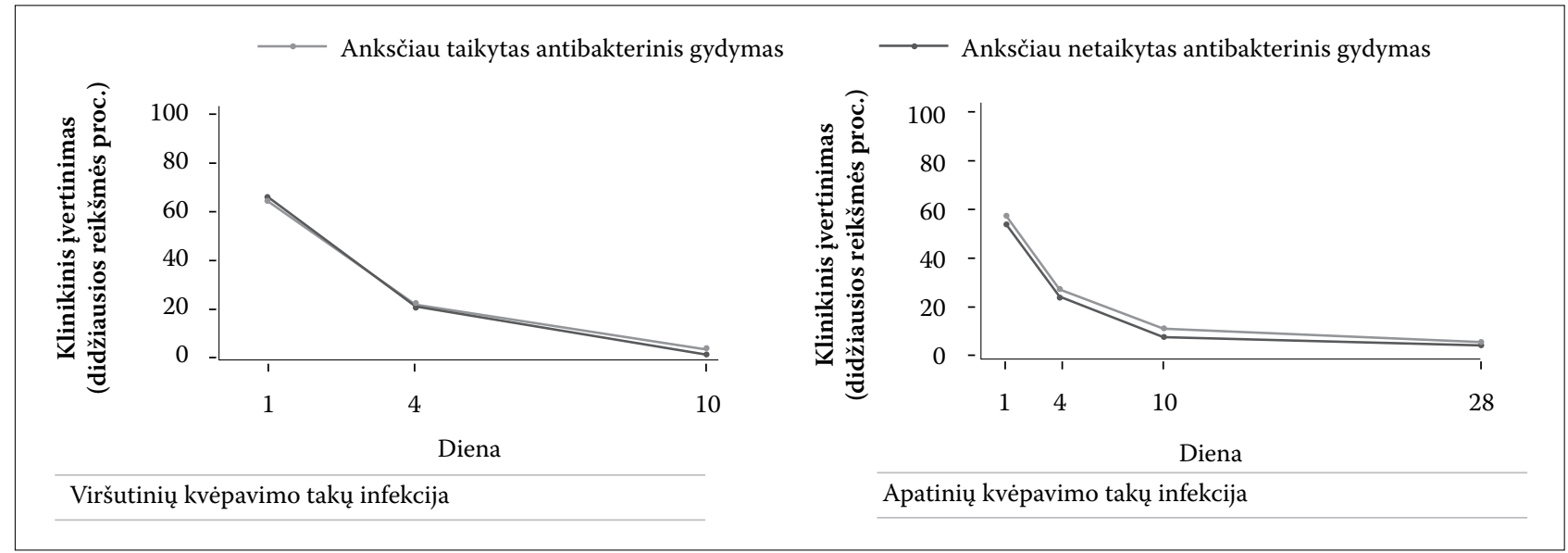

1 pav. Anksčiau taikyto antibakterinio gydymo j̧taka

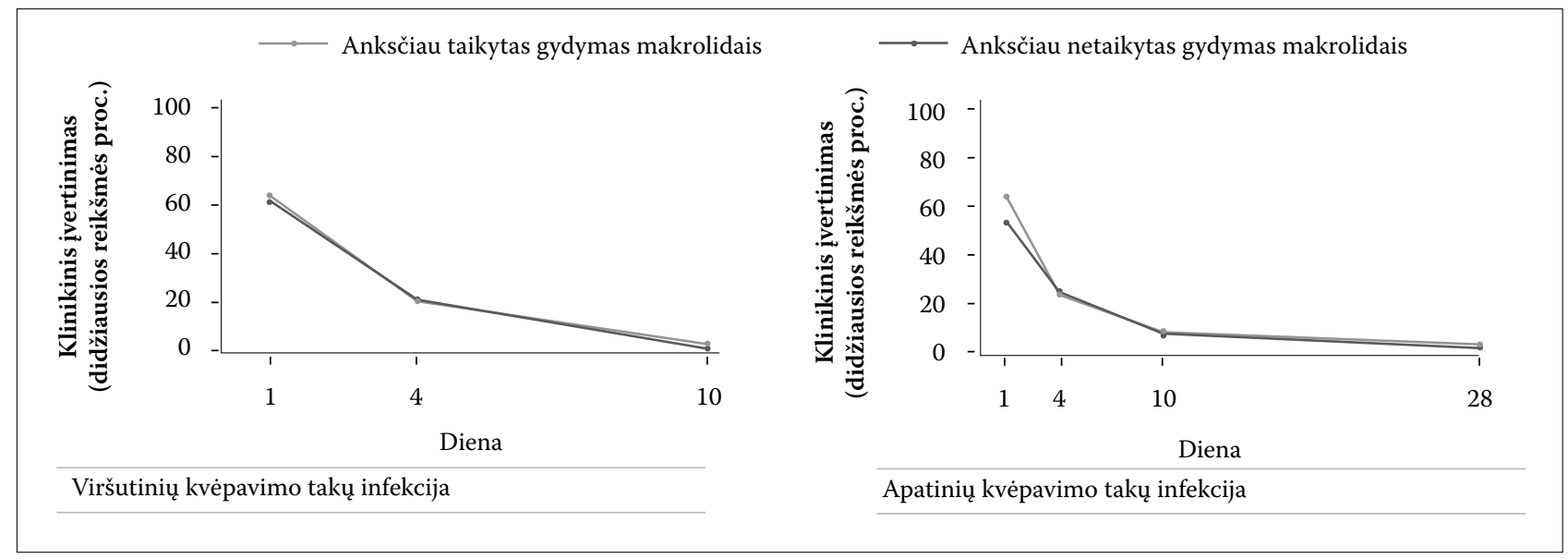

2 pav. Anksčiau taikyto gydymo makrolidais j̇taka

tepinèlio bakterioskopinis tyrimas) pagal nustatytą metodiką. Apžiūra buvo atliekama 1-ą, 4-ą, 10-ą (12-ą) dienomis esant viršutinių kvèpavimo takų infekcijoms bei papildomai 28-ą (32-ą) dieną sergant Vİ.

Po 10 dienų nuo gydymo Sumamed pradžios nustatyta, kad pasveikę ar pagerèję buvo daugiau kaip 95 proc. pacientų, sergančių viršutinių kvėpavimo taku infekcine liga, o po 28 dienų nuo gydymo Sumamed pradžios - daugiau kaip 93 proc. pacientų, sergančių apatinių kvèpavimo takų infekcine liga.

Dar vienas dalykas, vertintas šiame tyrime, - mikrobų atsparumas antibiotikams. Tuo tikslu buvo tiriamas Sumamed veiksmingumas po anksčiau taikyto antimikrobinio gydymo ir be jo (1 pav.). Pastebèta, kad prieš Sumamed taikytas gydymas antibiotikais neturèjo jokios įtakos gydymo rezultatams, t. y. atsparumas azitromicinui neišsivystè. Be to, ištirta ir kitoje grupeje irodyta, kad net po gydymo kitais makrolidais atsparumas azitromicinui neišsivystè ( 2 pav.).

Kitame tyrime vertintas ne tik azitromicino poveikis neutrofiluc funkcijai ir biocheminiam aktyvumui in $v i$ tro, bet ir tirtas poveikis įvairioms žmogaus neutrofilų funkcijoms bei kai kurių uždegimo mediatorių kiekio kitimui serume, siekiant patikslinti galimą azitromicino poveiki mediatorių atsipalaidavimui in vivo [23].
Šiame tyrime sveikiems vyriškosios lyties savanoriams buvo skirtas standartinis 3 dienų (500 mg per dieną) azitromicino kursas. Ivvairūs rodikliai įvertinti prieš pat gydymo kursą bei praejjus 2,5 ir 24 valandoms bei 28 dienoms po paskutinès vaisto dozès. Iš tiriamųjų kraujo buvo išskiriami ir analizuojami neutrofilai, pirminių azurofilinių granulių fermentai (mieloperoksidazè, chloroacetatesterazé, šarminè fosfatazè ir kt.), specifinių granulių sudètinès dalys neutrofilų lizatuose ir serume, neutrofilu oksidacinis aktyvumas, glutationo ir glutationperoksidazès koncentracija serume ir neutrofilų lizatuose, superoksiddismutazès aktyvumas ir bendras antioksidacinis statusas, nitritų ir nitratų koncentracijos plazmoje, neutrofilu apoptozès intensyvumas, chemokinų ir citokinų koncentracija serume, tirpių adhezijos molekulių bei ūminès fazès baltymų koncentracija serume [23].

Gauti rezultatai rodo, kad 3 dienas azitromiciną (Sumamed) vartojusiems sveikiems asmenims greitai pasireiškè poveikis neutrofiluc granulių fermentų atsipalaidavimui bei apsauginiams oksidaciniams mechanizmams. Tai siejama su didele pradine vaisto koncentracija plazmoje ir neutrofiluose. Azitromicinas sukelia neutrofiluc chemokinu ir interleukinų (IL-1, IL-6, IL-8) koncentraciju serume svyravimus (normalius) ir vèly- 
vą poveiki neutrofilu apoptozei bei tirpioms adhezijos molekulèms, o tai lemia ilgai išliekančią vaisto koncentraciją neutrofiluose.

Vartojant azitromiciną (Sumamed), neutrofiluose sumažèja, o serume padidèja neutrofilu mieloperoksidazès ir kai kurių kitų fermentų aktyvumas. Azitromicino sąlygota pradinè neutrofilu degranuliacija prisideda prie vaisto antibakterinio poveikio infekcijos vietose.

Buvo nustatytas ir kitas galimas azitromicino poveikis uždegimui. Neutrofilai ir kitos ląstelès gamina didelị kiekị IL-8 ir onkogeno- $\alpha$, kurie yra galingi neutrofilu funkcijos stimuliatoriai. IL-8 dar slopina neutrofiluc apoptozę. Tyrime nustatytas greitas slopinamasis azitromicino poveikis tiek cirkuliuojančiam IL-8, tiek ir onkogenui- $\alpha$.

Praejjus 24 val. po azitromicino suvartojimo serume sumažejo tirpių vaskulinių adhezijos molekulių-1 koncentracija. Tai rodo, kad azitromicinas gali slopinti tiek neutrofilu chemotaksio peptidu gamybą, tiek ir adhezijos molekulių aktyvinamų leukocitų atsipalaidavimą.

Buvo tiriamas ir neutrofilų oksidacinis atsakas (angl. oxidative burst) ì fagocitozę stimuliuojančias medžiagas. Suvartojus azitromicino, neutrofilu oksidacinis atsakas i fagocitozès stimuliatorius greitai sustiprèjo. Tai gali būti papildomas azitromicino poveikis, prisidedantis prie jo antibakterinio veikimo.

\section{APIBENDRINIMAS}

Klinikinių tyrimų rezultatai rodo, kad trijų dienų trukmès gydymas Sumamed yra efektyvus ir saugus gydant viršutinių bei apatinių kvèpavimo takų infekcines ligas kasdienëje klinikinėje praktikoje. Ankstesnis gydymas antimikrobiniais vaistiniais preparatais ir makrolidais Sumamed efektyvumui itakos neturi.

Galima teigti, kad Sumamed kursas sveikiems asmenims sąlygoja greitą stimuliuojamąji poveikị neutrofilu degranuliacijai bei oksidaciniam atsakui (sukeltam fagocitozès). Tai prisideda prie azitromicino antibakterinio veikimo. Kita vertus, greitas slopinamasis azitromicino poveikis cirkuliuojančiam IL-8, onkogenui- $\alpha$ bei tirpioms adhezijos molekulèms-1 gali rodyti azitromicino uždegimą slopinantị poveikị.

\section{THE ROLE OF OUTPATIENT-ADMINISTERED AZITHROMYCIN IN THE TREATMENT OF COMMUNITY ACQUIRED PNEUMONIA}

\section{RŪTA NUTAUTIENE் \\ DEPARTMENT OF PULMONOLOGY AND IMMUNOLOGY LITHUANIAN UNIVERSITY OF HEALTH SCIENCE}

Keywords: community acquired pneumonia, treatment, macrolides, azithromycin. Summary. Globally, community acquired pneumonia (CAP) is a quite frequent disease, and infectious agents thereof are identified in less than 50 $\%$ of all cases, and in outpatients are usually not investigated. According to research findings and recommendations, most CAPs are empirically treated with antibiotics, which must be effective against Streptococcus pneumoniae, Haemophilus influenzae, Mycoplasma pneumoniae, Chlamydia pneumoniae, and Legionella pneumophila. Macrolides, especially the new generation (azithromycin), have less toxicity and better pharmacokinetic properties, are the alternative medicines, used when the first-line treatment is not tolerated. Clinical studies demonstrated 3-day treatment efficacy and safety with azithromycin while treating upper and lower respiratory tract infections in everyday clinical practice.

\section{LITERATŪRA}

1. Bartlett JG, Mundy LM. Community-acquired pneumonia. N Engl J Med 1995:333:1618-24.

2. Danila E, Šatkauskas B. Pulmonologija. Vaistų žinios, 2003.

3. Bates JH, Campbell GD, Barron AL, McCracken GA, Morgan PN, Moses EB, Davis CM. Microbial etiology of acute pneumonia in hospitalized patients. Chest 1992;101:1005-12.

4. Fang GD, Fine $M$, Orloff J, et al. New and emerging etiologies for community acquired pneumonia with implications for therapy - prospective multicenter study of 359 cases. Medicine 1990;69:307-16.

5. Suaugusiuju apatiniu kvèpavimo taku ir plaučių infekciju diagnostikos ir gydymo rekomendacijos (lietuvos pulmonologu sutarimas). R.Sakalauskas, A. Bagdonas, E. Danila, K. Malakauskas ir kt.

6. Jones RN. Can antimicrobial activity be sustained? An appraisal of orally administered drugs used in respiratory tract infections. Diagn Microbiol Infect Dis 1997;27:21-8.

7. Appelbaum PC, Gladkova C, Hryniewicz W, et al. Carriage of antibiotic-resistant Streptococcus pneumoniae by children in eastern and central Europe - a multicenter study with use of standardized methods. Clin Infect Dis 1996;23:712-7.

8. Baquero $F$. Trends in antibiotic resistance of respiratory pathogens: an analysis and commentary on a collaborative surveillance study. J Antimicrob Chemother 1996; 38 (Suppl A):117-32.

9. Chambers HF. Neu HC. Penicillins. Principles and practice of Infectious Diseases, 4th edn. New York: Churchill Livinstone, 1995:233-46.

10. Pallares R, Linares J, et al. Resistance to penicillin and cephalosporin and mortality from severe pneumoccocal pneumonia in Barcelona, Spain. $\mathrm{N}$ Engl J Med 1995;333:474-80.

11. Ballow $\mathrm{CH}$, Jones RN, SPAR Study Group. Comparative in vitro assessment of sparfloxacin activity. Diagn Microbiol Infect Dis 1997;29:173-86.
12. Bermudez LE, Petrofsky M. Emergence of Mycobacterium avium populations resistant to macrolides during experimental chemotherapy. Antimicrob Agents Chemoter 1998;42:180-3.

13. Bauernfeid A, Eberlein E. Comparative pharmacodynamics of clarithromycin and azithromycin against respiratory pathogens. Infection 1995;23:316-21.

14. Cauchie P, Hubloux A. Carriage of antibiotic-resistant Streptococcus pneumoniae by children in eastern and central Europe. Clin Infect Dis 1998;23:712-7.

15. Foulds $G$, Madsen P. Concentration of azithromycin in human prostatic tissue. Eur J Clin Microbiol Infect Dis 1991;19 (Suppl) A:11-19.

16. Gemmel CG. Macrolides and host defences to respiratory tract pathogens. J Hosp Infect 1991;10:868-71.

17. Foulds $G$, Shepard RM. The pharmacokinetics of azithromycin in human serum and tissues. J Antimicrob Chemoter 1990;25 A:11-19.

18. Krohn K. Gynaecological tissue levels of azithromycin. Eur J Clin Microbiol Infect Dis 1991;10:864-8.

19. Langtry HD, Balfour JA. Azithromycin: a review of its use in paediatric infectious diseases. Drugs 1998:56:273-97.

20. Azithromycin. Drug Facts and Comparisons . Efacts [online]. 2005. Available from Wolters Kluwer Health, Inc. Accessed 3/16/05.

21. Zithromax ${ }^{\oplus}$ prescribing information. Pfizer Inc., January 2004.

22. Clinical effectiveness of azithromycin in an era of multidrug resistance: results of a prospective international, multicentre observational study (SUPORTI). B. Baršic (Zagreb, HR) 2010

23. Čulić $\mathrm{O}$, Eraković $\mathrm{V}$, et al. Azithromycin modulates neutrophil function and circulating inflammatory mediators in healthy human subjects. European Journal of Pharmacology 450 (2002) 277- 289. 